\title{
Nitrogen balance, blood metabolites and milk fatty acid composition of dairy cows fed pomegranate-peel extract
}

\author{
M.J. Abarghuei ${ }^{\text {a }}$, Y. Rouzbehan ${ }^{\text {a,* }}$, A.Z.M Salem ${ }^{\text {b,c }}$, M.J. Zamiri ${ }^{\mathrm{d}}$ \\ a Animal Science Department, Faculty of Agriculture, Tarbiat Modares University, P.O. Box 14115-336, Tehran, Iran \\ ${ }^{\mathrm{b}}$ Facultad de Medicina Veterinariay Zootecnia, Universidad Autónoma del Estado de México, Mexico \\ ${ }^{\mathrm{c}}$ Faculty of Agriculture, Alexandria University, Alexandria, Egypt \\ d Department of Animal Science, College of Agriculture, Shiraz University, Shiraz, Iran
}

\section{A R T I C L E I N F O}

\section{Article history:}

Received 15 January 2014

Received in revised form

21 March 2014

Accepted 21 March 2014

Keywords:

Blood parameters

Dairy cow

Milk fatty acid

Pomegranate peel extract

Nitrogen balance

\begin{abstract}
A B S T R A C T
An experiment was carried out to determine the effect of pomegranate peel extract (PPE) on nitrogen balance, blood parameters and the milk fatty acid profile of dairy cows. Four Holstein cows were used in a $4 \times 4$ Latin square design with 28 -d periods and 4 treatments: PPE0 (no extract), PPE400 (400 ml PPE/cow/d), PPE800 (800 ml PPE/cow/d) and PPE1200 (1200 ml PE/cow/d). Nitrogen balance, blood parameters and the milk fatty acid profile were measured. Determination of secondary metabolites showed its high content of aqueous fraction, total phenolics and total tannin with reasonable content of saponins. Outputs of $\mathrm{N}$ in milk were quadratically increased $(P=0.044)$ by inclusion of PPE at 400 and $800 \mathrm{ml} \mathrm{PPE} / \mathrm{cow} / \mathrm{d}$ in the diet. Blood cholesterol (quadratic effect, $P=0.043$ ), blood urea nitrogen (linear effect, $P=0.047$ ) and milk urea nitrogen (quadratic effect, $P=0.0008$ ) concentrations decreased with adding PPE. Supplementation with PPE quadratically lowered total saturated fatty acid $(P=0.005)$, proportions of $\mathrm{C} 12: 0$ (linear effect $=0.040$ ), $C 16: 1 c 9$ (quadratic effect, $P=0.011$ ), C18:0 (linear effect, $P=0.083$, quadratic effect, $P=0.011$ ) and $\omega 6 / \omega 3$ (quadratic effect, $P=0.007$ ). Amount of $\mathrm{C} 18: 3 c(n-3)$ (linear effect, $P=0.046$ ), DHA (C22:6) (quadratic effect, $P=0.009)$ and EPA (C20:5) (quadratic effect, $P=0.012$ ) were increased by inclusion of PPE. Adding PPE lowered blood cholesterol, blood urea nitrogen and milk urea nitrogen. Milk from cows fed PE had significantly lower total saturated fatty acid, desirable $\omega 6 / \omega 3$ ratio and higher content of EPA and DHA.
\end{abstract}

(c) 2014 Elsevier B.V. All rights reserved.

\footnotetext{
Abbreviations: ADF, ash-free acid detergent fiber; BUN, blood urea nitrogen; $\mathrm{CP}$, crude protein; DHA, Docosahexaenoic acid; DM, dry matter; DMI, Dry matter intake; EPA, Eicosapentaenoic acid; MUFA, monounsaturated fatty acid; MUN, milk urea nitrogen; $\mathrm{NE}_{\mathrm{L}}$, net energy for lactation; NDF, ash-free neutral detergent fiber; OM, organic matter; PP, pomegranate peel; PPE, pomegranate peel extract; PUFA, polyunsaturated fatty acid; SFA, saturated fatty acid; TMR, total mix ration; $\omega 6$, omega- 6 fatty acids; $\omega 3$, omega- 3 fatty acids.

* Corresponding author. Tel.: +9821 48292336; fax: +982148292200

E-mail address: rozbeh_y@modares.ac.ir (Y. Rouzbehan).
}

\section{Introduction}

In livestock production systems, different approaches such as antibiotics and ionophores have been used to improve feed efficiency and fatty acids profile in milk and maximize the performance of dairy cows. However, due to the public concern for adding antibiotics in livestock ration, great work has been devoted towards developing replacements to such additives. Plant secondary metabolites offer a chance in this regard (Benchaar et al., 2008). Plant secondary metabolites in tree leaves such as Salix babylonica, Leucaena leucocephala, and grape pomace 
extracts (Alipour and Rouzbehan, 2010; Salem et al., 2011, 2014a; Jiménez-Peralta et al., 2011) were found to improve the ruminal fermentation parameters and to enhance amino acid flow to the duodenum (Mueller-Harvey, 2006). This could lead to more muscle deposition and greater milk production (Vasta et al., 2008, Salem et al., 2014b). Also, plant secondary metabolites have been suggested as potential resources to manipulate bacterial populations involved in ruminal biohydrogenation to alter the fatty acid profile of ruminant-derived food products such as milk and meat. For example, Durmic et al. (2008) observed that ethanolic extracts and essential oils from some Australian plants increased the concentrations of unsaturated fatty acids in rumen fluid. In other study, Cabbidu et al. (2009) showed that in sheep fed Sulla (contain 25-27 g condensed tannin per kg DM), total trans fatty acids and $\omega 6 / \omega 3$ ratio content was lower comparing to sheep fed Sulla and polyethylene glycol, but linoleic and linolenic acid were higher.

Pomegranate peel (PP) is a by-product of extracting the juice from pomegranates, with annual production of more than 120,000 t in Iran (Mirzaei-Aghsaghali et al., 2011). The PP contains secondary metabolites such as saponin, polyphenolic compounds, primarily punicalagin and ellagitannins, which have been shown to possess antimicrobial, antioxidant, anti-inflammatory, antimitotic, and immune modulatory properties (Adams et al., 2006; Oliveira et al., 2010). In conventional processes, plant secondary metabolites are extracted from PP by using organic solvents (methanol, ethanol and acetone) which are costly techniques. It was verified that the extraction efficiencies of the secondary metabolites using organic solvents are comparable with that of water, which are less expensive and polluting (Abarghuei et al., 2013, 2014). Therefore, we hypothesized that inclusion of PPE to the diet would improve protein metabolism and milk fatty acids content. Hence, this experiment was carried out to assess the influence of administering three concentrations of water PPE, on nitrogen balance, blood metabolites and milk fatty acid profile in dairy cows.

\section{Materials and methods}

\subsection{Animal care}

The experiment was carried out according to The Care and Use of Agricultural Animals in Research and Teaching (FASS, 2010) guidelines. All procedures and guidelines involving animals were approved by the Animal Experiment Committee at Tarbiat Modares University, Tehran, Iran.

\subsection{Pomegranate peel extract}

Pomegranate peel was obtained from two main factories in Saveh city, Iran, using similar pomegranate varieties and processing methods. Sun-dried peel was extracted at $1 \mathrm{~g} \mathrm{PP} / \mathrm{ml}$ of water. The peel was soaked in tap water at $40{ }^{\circ} \mathrm{C}$ for $72 \mathrm{~h}$ in a closed tank. To maximize the extraction of plant secondary metabolites from the PP, the tank was incubated in a water bath at $40{ }^{\circ} \mathrm{C}$ for one hour. The contents, then, were immediately filtered by metal mesh extraction and the filtrate was stored at $4{ }^{\circ} \mathrm{C}$ for further use.

\subsection{Experimental design, cows and treatments}

The experiment was designed as a balanced $4 \times 4$ Latin squares for carryover effects, using 4 dairy cows with four 28 -d periods. The cows were enrolled in the experiment with average days in milk of $87 \pm 29$ and mean body weight of $616 \pm 53 \mathrm{~kg}$. Cows were housed in individual tie stalls and had free access to water during the experiment. A total mix ration (TMR, Table 1) was fed for ad libitum intake (5-10\% orts, on as-fed basis). The animals were randomly assigned to 1 of 4 treatments: (1) PPE0 (control, no PPE added), (2) PPE400 (400 ml PPE/cow per day), (3) PPE800 (800 ml PPE/cow per day), and (4) PPE1200 (1200 ml PPE/cow per day). The PPE was extracted daily and mixed into the feed mixture. Each experimental period lasted $28 \mathrm{~d}$ with $21 \mathrm{~d}$ for adaptation to the diet, and $7 \mathrm{~d}$ for sampling and data collection. All diets were formulated to have similar concentrations of $\mathrm{CP}$ and net energy for lactation $\left(\mathrm{NE}_{\mathrm{L}}\right)$ (NRC, 2001). Diets were offered in equal amounts 3 times daily (0600 h, $1400 \mathrm{~h}$ and, $2200 \mathrm{~h}$ ).

\subsection{Nitrogen balance}

Feed consumption was recorded daily by weighing feeds offered to and refused by the cows. Samples of the TMR, feed ingredients, and orts were collected daily and kept frozen. Samples were composited by period, dried at $55^{\circ} \mathrm{C}$ for $48 \mathrm{~h}$, ground through a $1 \mathrm{~mm}$ screen Wiley mill (standard model 4; Arthur M. Thomas, Philadelphia, PA,

Table 1

Ingredients and chemical composition (means \pm SD) of the TMR fed to lactating cows $(\mathrm{n}=4)$.

\begin{tabular}{ll}
\hline Ingredients (g/kg DM) & \\
Alfalfa hay & 229.0 \\
Corn silage & 211.9 \\
Barley, rolled & 134.5 \\
Corn grain, ground, dry & 81.9 \\
Wheat bran & 99.4 \\
Wheat grain, rolled & 27.7 \\
Soybean meal & 66.3 \\
Canola meal & 28.0 \\
Cottonseed meal & 39.3 \\
Vegetable oil & 12.4 \\
Limestone & 6.2 \\
Mineral+ vitamin premix ${ }^{\mathrm{a}}$ & 12.4 \\
Salt & 6.2 \\
Molasses, beet sugar & 14.5 \\
Sodium bicarbonate & 12.4 \\
Fish meal & 17.0 \\
Chemical composition (g/kg DM) & \\
DM & \\
OM & $603 \pm 3.5$ \\
CP & $926 \pm 4.6$ \\
NDFom & $160 \pm 7.6$ \\
ADFom & $340 \pm 2.5$ \\
NE ${ }^{b}$, (Mcal/kg) & $201 \pm 1.2$ \\
\hline
\end{tabular}

a Contained 196 g Ca, 96 g P, 71 g Na, 19 g Mg, 3 g Fe, 0.3 g Cu, 2 g Mn, $3 \mathrm{~g} \mathrm{Zn} \mathrm{(per} \mathrm{kg);} 100$ ppm Co, 100 ppm I, $0.1 \mathrm{ppm} \mathrm{Se}$; and $50 \times 10^{5} \mathrm{IU}$ vitamin $\mathrm{A}, 10 \times 10^{5} \mathrm{IU}$ vitamin $\mathrm{D}$ and $0.1 \mathrm{~g}$ vitamin $\mathrm{E} / \mathrm{kg}$.

${ }^{b}$ Estimated from NRC (2001). 
US). Fecal grab samples were collected from all cows about $4 \mathrm{~h}$ pre-feeding (a.m. sampling) and $4 \mathrm{~h}$ post-feeding (p.m. sampling) on d 21 to 28 . Fecal samples were transferred to aluminum pans and held at $60{ }^{\circ} \mathrm{C}$ in a forced-air oven until completely dry. Fecal samples were then ground to pass a 1-mm Wiley mill screen, and a single composite was prepared for each cow by mixing equal DM from both samples. Samples of the TMR, orts and fecal samples were analyzed for DM, OM, ash-free neutral detergent fiber (NDF), ash-free acid detergent fiber (ADF) and total N. At the times of fecal sampling, spot urine samples were obtained from all cows by stimulation of the vulva. After collection, $15 \mathrm{ml}$ of urine was pipetted into specimen containers holding $60 \mathrm{ml}$ of $0.072 \mathrm{~N} \mathrm{H}_{2} \mathrm{SO}_{4}$ and stored at $-20{ }^{\circ} \mathrm{C}$ until analysis.

\subsection{Blood sampling and analyses}

On d 27 of each period and at 11:30 h, blood was collected from the jugular vein into tubes containing $\mathrm{Na}$ heparin. Blood was centrifuged at $14,000 \mathrm{~g}$ for $15 \mathrm{~min}$ at $10{ }^{\circ} \mathrm{C}$ to obtain serum. Glucose, albumin, total protein, triglycerides, cholesterol and urea nitrogen (BUN), were measured using enzymatic procedures and commercial kits (Pars Azmon Co., Tehran, Iran).

\subsection{Milking and milk fatty acids composition}

Cows were milked 3 times daily $(0500 \mathrm{~h}, 1300 \mathrm{~h}$ and $2100 \mathrm{~h}$ ) and the amount of milk produced for each cow at each milking was recorded using special graduated jars (Agri and SD Co., Frankfurt, Germany). Before each milking, cows were monitored for udder inflammation and presence of milk clots in the teats to ensure that milk yield and composition were not affected by mastitis. During the last week of each 28 -d period, milk samples were taken from each cow at each milking and stored at $-80{ }^{\circ} \mathrm{C}$ until analyzed for fatty acid composition.

\subsection{Analytical methods}

Nitrogen content in feed, feces and urine was determined by the Kjeldahl method (AOAC, 1990; method 954.01). Ash-free neutral detergent fiber (NDF) and ashfree acid detergent fiber (ADF) content were analyzed according to Van Soest et al. (1991) using the ANKOM F-57 filter bags in an Ankom ${ }^{200}$ Fiber Analyzer unit (Ankom Technolgy, Macedon, N.Y. USA). For NDF analysis, samples were treated with $\alpha$-amylase (Sigma A-3403 Sigma-Aldrich ${ }^{\circledR}$ Co., Louis MO, USA), and the neutral detergent solution contained sodium sulfite and the residues were not corrected for residual ash. Daily urine volume was estimated from urinary creatinine concentration and body weight (Valadares et al., 1999). After thawing at room temperature, the urine sample was filtered through Whatman no. 1 filter paper; the filtrate was analyzed for creatinine. The mean daily creatinine excretion rate $(29.0 \mathrm{mg} / \mathrm{kg}$ of body weight per d) was computed using the data from all cows in the trial. Urine volume was used to compute daily excretion of urea, and allantoin, and uric acid from spot urine samples were estimated: body weight $\times 29 /$ creatinine concentration $(\mathrm{mg} / \mathrm{l}$ ) (Valadares et al., 1999).

For analysis of milk fatty acids, fatty acids methyl esters were ready by base-catalyzed transmethylation (Chouinard et al., 1997). Composition of fatty acids in TMR samples was determined according to the method of Sukhija and Palmquist (1988). Fatty acid analyses were carried out with a gas chromatograph (HP 5890A Series II, Hewlett Packard, Palo Alto, CA) equipped with a 100-m CP-Sil 88 capillary column (i.d., $0.25 \mathrm{~mm}$; film thickness, $0.20 \mu \mathrm{m}$; Chrompack, Middelburg, the Netherlands) and a flameionization detector (Farnworth et al., 2007).

Fatty acids were expressed as the proportion of each individual fatty acid to the total of all fatty acids present in the sample. The following fatty acid combinations were

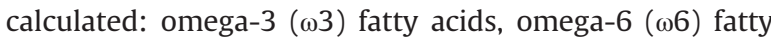
acids, total saturated fatty acids (SFA), total monounsaturated fatty acids (MUFA), polyunsaturated fatty acids (PUFA), total unsaturated fatty acids (UFA) and $\omega 6 / \omega 3$ ratio.

Total phenolics were measured using the Folin-Ciocalteau method (Makkar, 2000). Extract (200 mg) dissolved in acetone: water $(10 \mathrm{ml} ; 70: 30, \mathrm{v} / \mathrm{v})$ in an ultrasonic bath for $20 \mathrm{~min}$. The contents were centrifuged $\left(4^{\circ} \mathrm{C}, 10 \mathrm{~min}, 3000 \mathrm{~g}\right)$ and the supernatant was kept on ice until analysis. Non tannin phenolics were determined using absorption to insoluble polyvinylpyrrolidone (Sigma-Aldrich Chemie GmbH, Steinheim, Germany). The insoluble polyvinylpyrrolidone (100 mg) was weighed into $100 \mathrm{~mm} \times 12 \mathrm{~mm}$ test tubes. Distilled water, $1 \mathrm{ml}$, and then $1 \mathrm{ml}$ tannin containing extract were added and vortexed. The tube was kept at $4{ }^{\circ} \mathrm{C}$ for $15 \mathrm{~min}$, vortexed again, and centrifuged (3000g) for $10 \mathrm{~min}$ and the supernatant collected. Phenolic content in the supernatant was measured by the Folin-Ciocalteau reaction and this was accepted as the non-tannin phenol (Makkar, 2000). Total tannins were calculated as the difference between total phenols and non-tannin phenol. Tannic acid (Merck GmbH, Darmstadt, Germany) was used as the standard to express the amount of total phenols and total tannins. Condensed tannins were measured by the $\mathrm{HCl}$-butanol method (Makkar, 2000). An aliquot from the above acetone:water extract $(0.5 \mathrm{ml})$ plus $\mathrm{HCl}$-butanol $(3 \mathrm{ml})$ and ferric ammonium sulfate $(0.1 \mathrm{ml})$ reagents were heated in a boiling water bath for $60 \mathrm{~min}$. Absorbance was read at $550 \mathrm{~nm}$. Hydrolysable tannins were analyzed using rhodanine assay according to Makkar (2000). The results were expressed as gallotannin.

Ten milliliters of the extract were prepared after total phenols separation; a double volume of n-butanol was added to fractionate saponins (Makkar et al., 1998). The remaining solution was considered to be the aqueous fraction containing other secondary compounds such lectins, polypeptides and starch (Cowan, 1999). Dihydromaltol, butanoic acid, 3-methyl-hexyl ester and thymol were measured by gas chromatography/mass spectrometry (GC/MS).

\subsection{Statistical analysis}

Data were analyzed as a $4 \times 4$ Latin square, simple changeover, design using the MIXED procedure (SAS Inst. Inc., Cary, NC), using the statistical model:

$Y_{i j k}=\mu+A_{i}+P_{j}+T_{k}+e_{i j k}$ 
where $Y_{i j k}$ is a dependent variable, $\mu$ is the overall mean, $A_{i}$ is the effect of cow $i, P_{j}$ is the effect of period $j, T_{k}$ is the fixed effect of dose $k$, and $e_{i j k}$ is the residual (random error). The contrast statement was used to determine the linear and quadratic cow response to increasing concentrations of the extract in the diet. Differences between treatments were declared significant at $P \leq 0.05$ using the Tukey correction for multiple comparisons, and trends were discussed at $P \leq 0.10$ unless otherwise stated.

\section{Results}

\subsection{Active secondary metabolites of PPE and composition of the TMR}

The content of active secondary metabolites of PPE of the basic TMR which was analyzed on the mix fed to cows is shown in Table 2. PPE extract contained a considerable amount of total phenolics and total tannins with reasonable amounts of saponins. It also contained a large content of aqueous fraction (Table 2).

\subsection{Nitrogen balance}

There were no significant effects $(P>0.05)$ of the extract on Intake of $\mathrm{N}$, outputs of $\mathrm{N}$ in feces and urine and $\mathrm{N}$ balance but, outputs of $\mathrm{N}$ in milk were quadratically increased $(P=0.044)$ by inclusion of PE400 and PE800 in the diet (Table 3 ).

\subsection{Blood metabolites}

Blood glucose, albumin and triglyceride concentrations were not changed by feeding PPE, although blood cholesterol (quadratic effect, $P=0.043$ ) and BUN (linear effect, $P=0.047$ ) were decreased with adding PPE (Table 4). Addition of PPE quadratically decreased $(P=0.0008)$ MUN (Table 4).

\subsection{Milk fatty acid composition}

Addition of PPE leaded to in some modifications of milk fatty acid profile as suggested by the lowered SFA (quadratic

Table 2

Secondary metabolites levels ( $\mathrm{g} / \mathrm{kg}$ DM diet) of PPE.

\begin{tabular}{|c|c|c|c|c|c|}
\hline \multirow[t]{2}{*}{ Secondary compounds } & \multirow[t]{2}{*}{ mg/ml extract } & \multicolumn{4}{|c|}{ Treatment $^{\mathrm{a}}$} \\
\hline & & $\begin{array}{l}\text { PPE0 } \\
\mathrm{g} / \mathrm{kg} \text { diet }\end{array}$ & PPE400 & PPE800 & PPE1200 \\
\hline Total phenolics & 65 & 3.50 & 4.56 & 5.58 & 6.6 \\
\hline Total tannins & 56 & 1.00 & 1.92 & 2.80 & 3.66 \\
\hline Condensed tannins & 0.08 & - & 0.0014 & 0.0026 & 0.0038 \\
\hline Hydrolyzable tannins & 6.3 & - & 0.11 & 0.22 & 0.33 \\
\hline Saponins & 35.5 & 11.40 & 11.98 & 12.54 & 13.09 \\
\hline Aqueous fraction ${ }^{\mathrm{b}}$ & 227.9 & - & 3.73 & 7.30 & 10.85 \\
\hline Dihydromaltol & 0.005 & - & 0.00008 & 0.00016 & 0.00024 \\
\hline Butanoic acid, 3-methyl-hexyl ester & 0.002 & - & 0.00084 & 0.00168 & 0.00252 \\
\hline Thymol & 0.003 & - & 0.00004 & 0.00009 & 0.00013 \\
\hline
\end{tabular}

Table 3

Nitrogen balance in lactating cows fed PPE- supplemented diets.

\begin{tabular}{|c|c|c|c|c|c|c|}
\hline \multirow[t]{2}{*}{ Treatment $^{1}$} & \multicolumn{6}{|c|}{ Parameters (g/d) } \\
\hline & DMI & Intake $\mathrm{N}$ & Urine $\mathrm{N}$ & Fecal N & Milk N & Balanced N \\
\hline PPE0 & 26.2 & 670 & 174 & 272 & $157^{\mathrm{b}}$ & 66.2 \\
\hline PPE400 & 24.4 & 626 & 174 & 241 & $172^{\mathrm{a}}$ & 39 \\
\hline PPE800 & 23.8 & 609 & 171 & 242 & $173^{\mathrm{a}}$ & 23 \\
\hline PPE1200 & 25.3 & 646 & 173 & 254 & $164^{\mathrm{ab}}$ & 55 \\
\hline $\mathrm{SEM}^{2}$ & 0.74 & 18.9 & 17.7 & 9.0 & 4.9 & 22.2 \\
\hline \multicolumn{7}{|l|}{$P$-value } \\
\hline Linear & 0.667 & 0.350 & 0.940 & 0.237 & 0.369 & 0.645 \\
\hline Quadratic & 0.391 & 0.076 & 0.963 & 0.054 & 0.044 & 0.226 \\
\hline
\end{tabular}

${ }^{\mathrm{a}, \mathrm{b}}$ Means within a column with different superscripts differ $(P<0.05)$ using $t$-test for pairwise comparison.

1 Treatments: PPE0 $=$ control, no additive; PPE $400=400 \mathrm{ml}$ pomegranate peel extract $/$ cow $/ \mathrm{d} ; \mathrm{PPE} 800=800 \mathrm{ml}$ pomegranate peel extract $/ \mathrm{cow} / \mathrm{d}$; PPE1200 = $1200 \mathrm{ml}$ pomegranate peel extract $/ \mathrm{cow} / \mathrm{d}$.

${ }^{2} \mathrm{SEM}=$ Standard error of the mean. DMI: Dry matter intake $(\mathrm{kg} / \mathrm{d})$. 
Table 4

Blood metabolites in lactating dairy cows fed PPE-supplemented diets.

\begin{tabular}{|c|c|c|c|c|c|c|c|}
\hline \multirow[t]{2}{*}{ Treatment $^{1}$} & \multicolumn{7}{|l|}{ Parameters } \\
\hline & Glucose (mg/dl) & Albumin (g/dl) & Total protein (g/dl) & Triglyceride (mmol/dl) & Cholesterol (g/dl) & BUN (g/dl) & $\operatorname{MUN}(\mathrm{g} / \mathrm{dl})$ \\
\hline PPE0 & 66.7 & 3.5 & 7.1 & 0.195 & $210^{\mathrm{a}}$ & $24.4^{\mathrm{a}}$ & $14.5^{\mathrm{a}}$ \\
\hline PPE400 & 68.6 & 3.4 & 7.6 & 0.198 & $162^{\mathrm{b}}$ & $18.8^{\mathrm{b}}$ & $12.1^{\mathrm{b}}$ \\
\hline PPE800 & 75.9 & 3.5 & 7.8 & 0.197 & $160^{\mathrm{b}}$ & $18^{\mathrm{b}}$ & $11.5^{\mathrm{b}}$ \\
\hline PPE1200 & 72.3 & 3.4 & 7.5 & 0.192 & $215^{\mathrm{a}}$ & $19.2^{\mathrm{b}}$ & $13.9^{\mathrm{b}}$ \\
\hline $\mathrm{SEM}^{2}$ & 3.26 & 0.09 & 0.23 & 0.003 & 19.8 & 1.48 & 0.38 \\
\hline \multicolumn{8}{|l|}{$P$-value } \\
\hline Linear & 0.149 & 0.411 & 0.235 & 0.295 & 0.875 & 0.047 & 0.186 \\
\hline Quadratic & 0.426 & 0.828 & 0.191 & 0.584 & 0.043 & 0.059 & 0.001 \\
\hline
\end{tabular}

${ }^{\mathrm{a}, \mathrm{b}}$ Means within a column with different superscripts differ $(\mathrm{P}<0.05)$ using $t$-test for pairwise comparison.

${ }^{1}$ Treatments: PPE0 $=$ control, no additive; PPE $400=400 \mathrm{ml}$ pomegranate peel extract $/ \mathrm{cow} / \mathrm{d} ; \mathrm{PPE} 800=800 \mathrm{ml}$ pomegranate peel extract $/ \mathrm{cow} / \mathrm{d}$ PPE1200 $=1200 \mathrm{ml}$ pomegranate peel extract $/ \mathrm{cow} / \mathrm{d}$.

${ }^{2} \mathrm{SEM}=$ Standard error of the mean.

Table 5

Milk fatty acid profile (g/100 g of total fatty acids) of cows fed PPE.

\begin{tabular}{|c|c|c|c|c|c|c|c|}
\hline \multirow[t]{2}{*}{ Fatty acid } & \multicolumn{4}{|c|}{ Treatments $^{1}$} & \multirow[t]{2}{*}{$\mathrm{SEM}^{2}$} & \multicolumn{2}{|l|}{$P$-value } \\
\hline & PPE0 & PPE400 & PPE800 & PPE1200 & & Linear & Quadratic \\
\hline C10:0 & 0.78 & 0.67 & 0.64 & 0.54 & 0.097 & 0.133 & 0.949 \\
\hline C12:0 & $1.08^{\mathrm{a}}$ & $0.83^{\mathrm{ab}}$ & $0.87^{\mathrm{ab}}$ & $0.68^{\mathrm{b}}$ & 0.099 & 0.040 & 0.824 \\
\hline C14:0 & 3.65 & 2.93 & 3.39 & 2.84 & 0.308 & 0.197 & 0.798 \\
\hline $\mathrm{C} 14: 1 c 9$ & 0.23 & 0.21 & 0.37 & 0.24 & 0.033 & 0.313 & 0.156 \\
\hline C16:0 & 12.60 & 10.17 & 12.29 & 11.76 & 0.911 & 0.921 & 0.337 \\
\hline C16:1 c9 & 0.46 & 0.47 & 0.59 & 0.46 & 0.018 & 0.260 & 0.011 \\
\hline C17:0 & 0.19 & 0.14 & 0.18 & 0.16 & 0.020 & 0.575 & 0.550 \\
\hline C17:1 & 0.18 & 0.15 & 0.19 & 0.18 & 0.011 & 0.385 & 0.340 \\
\hline C18:0 & $3.46^{\mathrm{a}}$ & $2.41^{\mathrm{b}}$ & $2.29^{\mathrm{b}}$ & $2.83^{\mathrm{ab}}$ & 0.219 & 0.083 & 0.011 \\
\hline$\sum C 18: 1$ & 0.08 & 0.11 & 0.50 & 0.09 & 0.209 & 0.684 & 0.338 \\
\hline$\sum C 18: 1 c$ & 6.73 & 5.14 & 6.17 & 6.30 & 0.463 & 0.905 & 0.112 \\
\hline C18:2 c (n-6) & 0.74 & 0.60 & 0.77 & 0.81 & 0.068 & 0.258 & 0.232 \\
\hline $\mathrm{C} 18: 3 c(\mathrm{n}-3)$ & $0.11^{\mathrm{cb}}$ & $0.10^{\mathrm{b}}$ & $0.13^{\mathrm{a}}$ & $0.11^{\mathrm{b}}$ & 0.004 & 0.046 & 0.274 \\
\hline C20:0 & 0.15 & 0.07 & 0.05 & 0.11 & 0.029 & 0.426 & 0.055 \\
\hline C20:1 & 0.03 & 0.02 & 0.04 & 0.02 & 0.003 & 0.584 & 0.168 \\
\hline C20:3 & $0.03^{\mathrm{a}}$ & $0.007^{\mathrm{b}}$ & $0.03^{\mathrm{a}}$ & $0.02^{\mathrm{a}}$ & 0.003 & 0.764 & 0.023 \\
\hline C20:4 & $0.05^{\mathrm{a}}$ & $0.02^{\mathrm{b}}$ & $0.04^{\mathrm{a}}$ & $0.05^{a}$ & 0.004 & 0.067 & 0.011 \\
\hline $\mathrm{C} 22: 0$ & $0.01^{\mathrm{a}}$ & $0.00^{\mathrm{b}}$ & $0.01^{\mathrm{a}}$ & $0.01^{\mathrm{a}}$ & 0.002 & 0.012 & 0.014 \\
\hline C22:1 & 0.006 & 0.00 & 0.008 & 0.01 & 0.003 & 0.163 & 0.206 \\
\hline DHA (C22:6) & $0.006^{\mathrm{b}}$ & $0.06^{\mathrm{a}}$ & $0.04^{\mathrm{a}}$ & $0.01^{\mathrm{b}}$ & 0.008 & 0.575 & 0.009 \\
\hline EPA (C20:5) & $0.001^{\mathrm{b}}$ & $0.05^{\mathrm{a}}$ & $0.03^{\mathrm{ab}}$ & $0.01^{\mathrm{b}}$ & 0.007 & 0.707 & 0.012 \\
\hline$\omega 6 / \omega 3$ & $7.00^{\mathrm{a}}$ & $2.98^{\mathrm{b}}$ & $4.20^{\mathrm{b}}$ & $6.88^{a}$ & 0.559 & 0.872 & 0.001 \\
\hline
\end{tabular}

a,b,c Means within a row with different superscripts differ $(P<0.05)$ using $t$-test for pairwise comparison.

${ }^{1}$ Treatments: $\mathrm{PPE} 0=$ control, no additive; PPE400 $=400 \mathrm{ml}$ pomegranate peel extract $/ \mathrm{cow} / \mathrm{d} ; \mathrm{PPE} 800=800 \mathrm{ml}$ pomegranate peel extract $/ \mathrm{cow} / \mathrm{d}$; PPE1200=1200 ml pomegranate peel extract/cow/d. DHA: Docosahexaenoic acid; EPA: Eicosapentaenoic acid; $\omega 6$ : omega-6 fatty acids (i.e., C18:2 c (n-6)+ C20:3+C20:4); $\omega 3$ : omega-3 fatty acids (i.e., C18:3 c (n-3)+DHA+EPA).

${ }^{2} \mathrm{SEM}=$ Standard error of the mean.

effect, $P=0.005$ ), proportions of $\mathrm{C} 12: 0$ (linear effect, $P=0.040$ ), C16:1 c9 (quadratic effect, $P=0.011$ ), C18:0 (linear effect, $P=0.083$, quadratic effect, $P=0.011$ ) and $\omega 6 / \omega 3$ (quadratic effect, $P=0.007)$. Amount of $C 18: 3 c(n-3)$ (linear effect, $P=0.046$ ), DHA (quadratic effect, $P=0.009$ ) and EPA (quadratic effect, $P=0.012$ ) were increased by inclusion of PPE. Concentrations of MUFA and PUFA were not affected by addition of PPE in the diet (Table 5).

\section{Discussion}

\subsection{Nitrogen balance}

Adding PPE had no effect on the $\mathrm{N}$ balance which is due to the lack of any influence on protein digestibility (Abarghuei et al., 2013). Similarly, Vaithiyanathan et al. (2007) found that adding secondary metabolite (69 g 
tannins/kg DM) had no effect on $\mathrm{N}$ balance of sheep. However, Woodward and Reed (1997) noted an improvement in the $\mathrm{N}$ balance in sheep fed $45 \mathrm{~g}$ condensed tannins/d. They illustrated that the improvement in the $\mathrm{N}$ balance in those sheep is due to the compensation for some fecal nitrogen loss by recycling nitrogen from blood to the rumen as a result of tannin presence in the fed diets. Inconsistently, Abarghuei et al. (2010) found that sheep fed diets contained $70.5 \mathrm{~g}$ total penolics/kg DM and $49.7 \mathrm{~g}$ total tannin $/ \mathrm{kg}$ DM have decreased nitrogen balance in comparison to those without tannin.

However, inclusion of PPE400 and PPE800 in the diet was increased milk $\mathrm{N}$ content. The increased daily milk $\mathrm{N}$ in cows may be due to decline in degradability of protein in rumen and an increase in the flow of microbial protein to the intestine, benefiting the cows by increasing the amount of amino acids available for absorption in small intestine (Makkar, 2003). In contrast to this study, Benchaar et al. (2007) reported that using $750 \mathrm{mg}$ mix essential oils/d in dairy cows diet had no influence on milk $\mathrm{N}$ content.

\subsection{Blood metabolites}

The lack of differences in blood concentrations of glucose and triglyceride with PPE supplementation was consistent with its lack of effect on DM intake. Similar to our result, Yang et al. (2010) observed no effects on glucose and triglyceride in blood of growing beef fed with 400, 800 and $1600 \mathrm{mg}$ eugenol/d supplementation. This observation is in contrast to other study of Makkar et al. (1995) who demonstrated that the presence of condensed tannin increased the molar proportion of propionate, a glucogenic precursor formed in the rumen which may have been expected to increase blood glucose concentration (Makkar et al., 1995). Blood total protein concentration is an indicator of the long-term protein status of dairy cows (Topps and Thompson, 1984) and no effect on total protein content of blood in our study represents the normal protein. Similarly, Nasri and Ben Salem (2012) reported that oral administration of Agave Americana extracts (containing 120, 240 and $360 \mathrm{mg}$ saponins/kg DM) or Quillaja saponaria (containing $120 \mathrm{mg}$ saponins/kg DM) to Barbarine female lamb had no effect on blood total protein concentration. In contrast, Sinclair et al. (2009) showed that inclusion of whole-crop pea silages differing in their tannin content decreased blood total protein. The addition of PPE to dairy cow diets decreased blood cholesterol concentration. It is well established that saponins form insoluble complexes with cholesterol (Nasri and Ben Salem, 2012; Shi et al., 2004). It is generally accepted that the principal action of saponins on blood cholesterol is by a direct binding between saponins and dietary cholesterol in the gut, which prevents its absorption from the small intestine. Secondly, a binding between saponins and bile acids in the gut may lead to decrease the enterohepatic circulation of bile acids and increase cholesterol excretion with feces. Saponins form micelles with cholesterol. The hydrophobic portion of the saponin (the aglycone or sapogenin) attaches (lipophilic bonding) to the hydrophobic sterol nucleus, in a stacked micellar combination
(Oakenfull and Sidhu, 1989). These results are consistent with the findings of Nasri and Ben Salem (2012) who illustrated administration of Agave Americana extracts to Barbarine female lamb decreased blood cholesterol concentration. Contrasting results were reported by Chiofalo et al. (2012) who noted dietary supplementation of 600 and 1200 mg extract of Rosmarinus officinalis L. per day had no effect on blood cholesterol concentration of dairy ewes. BUN concentrations were normal range of $6-27 \mathrm{mg} / \mathrm{dl}$. In the present experiment, a significant effect of PPE addition on BUN was observed. Lowered BUN may be due to decrease proteolysis in rumen and decline in ammonia production and reduced absorption of ammonia from the rumen and enter to blood. Similarly, it was shown that blood urea nitrogen, ruminal ammonia, and urinary $\mathrm{N}$ loss were lower when sheep and goats were fed legumes that contained tannins (Woodward, 1988). Additionally, other studies showed that saponins could decrease ammonia production in the rumen and thus affecting blood urea concentration (Francis et al., 2002; Wina et al., 2005). In contrast, Nasri and Ben Salem (2012) reported that BUN concentration was not affected by oral administration of Agave Americana extracts or Quillaja saponaria. These researchers reported that absence of effect of this extract on blood urea could be due to the low concentrations of saponins administered to lambs.

For all treatments, MUN concentrations were within the normal range of $10-14 \mathrm{mg} / \mathrm{dl}$. MUN concentrations are closely related to blood urea $\mathrm{N}$ concentrations and can be used as an indicator of protein utilization (Cannas et al., 1998).

\subsection{Milk fatty acids composition}

There is limited information on the use of secondary metabolites (such as phenolics, tannins and saponins) to alter the ruminal biohydrogenation process and manipulate milk fatty acid profile (Benchaar and Chauinard, 2009). Total SFA were lower in the milk of PPE-supplemented cows compared with animals not received PPE, that may be due to inhibit ruminal biohydrogenasion (Vasta et al., 2009; Khiaosa-Ard et al., 2009). Similarly, Vasta et al. (2009) had shown that tannin supplementation lowered the accumulation of SFA in milk of sheep. Dietary saturated fat intake has been shown to increase low density lipoprotein cholesterol, and therefore has been associated with increased risk of cardiovascular disease (Siri-Tarino et al., 2010; Steijns, 2008). Therefore, lowered SFA can be useful. PPE supplement increased EPA and DHA, indicating that secondary metabolites may protect lipids of ruminal biohydrogenation (Vasta et al., 2009) and inhibit growth and metabolism bacteria that are capable of biohydrogenation (Vasta et al., 2009; Mapiye et al., 2010). Therefore protection of fatty acids from ruminal biohydrogenation or inhibition of ruminal bacteria activity by PPE metabolites could have produced higher escape of fatty acids from rumen to tissue and milk. Additionally, once this fatty acids such as C18:3 $c(n-3)$ is converted by desaturase and elongase enzymes into nutritionally important long-chain (20-22) polyunsaturated fatty acids such as EPA and DHA (Brenna et al., 2009; Harris et al., 2009).Thus, apart from 
ruminal production, the higher amount of EPA and DHA obtained in milk fat of cows fed the PPE might have arisen from increased endogenous biosynthesis of this fatty acid from C18:3 $c(n-3)$ in the breast tissue. Recent reviews have reported that the metabolic conversion efficiency of C18:3 $c(n-3)$ to n-3 PUFA in humans is low and as result n-3 PUFA are now regarded as dietary essential (MolendiCoste et al., 2011; Harris et al., 2009). Even with the limited capacity of metabolic conversion of $\mathrm{C} 18: 3 c(n-3)$ to $n-3$ PUFA (Burdge and Calder, 2005; Givens, 2010), it has many roles in human health that are independent from its conversion to n-3 PUFA (Zhao et al., 2007; Hassan et al., 2010). The long chain n-3 PUFA plays a significant role in prevention of certain diseases and disorders such as cardiovascular diseases, hypertension, type 2 diabetes, irritable bowel syndrome, muscular degeneration, rheumatoid arthritis, asthma, psychiatric disorders and several cancers (Givens, 2010; McAfee et al., 2010; Micha et al., 2010). To decrease the risk of these diseases in humans, nutritionists recommend dietary intake for C18:3 c (n-3) of between 1.1 and $2.5 \mathrm{~g} / \mathrm{d}$ and between 200 and $600 \mathrm{mg} / \mathrm{d}$ for EPA plus DHA (Smit et al., 2009; USDA and HHS, 2010; Molendi-Coste et al., 2011). Similarly, Mapiye et al. (2010) reported that beef fed with Acacia karroo (contains $7.4 \mathrm{~g}$ condensed tannin/kg DM) have more EPA and DHA comparing to those fed control diet. In contrast, Cabbidu et al. (2009) showed that in sheep fed Sulla (contain 25-27 g condensed tannin $/ \mathrm{kg}$ DM), DHA content was lower comparing to sheep fed Sulla and polyethylene glycol, but EPA was not significant.

Addition of PPE decreased $\omega 6 / \omega 3$ ratio in cow's milk. It has been reported that decreased $\omega 6 / \omega 3$ ratio has a valuable influence on the healthiness of dairy products (Cabbidu et al., 2009). A lower ratio of $\omega 6 / \omega 3$ fatty acids is more desirable in reducing the risk of many of the chronic diseases of high prevalence for example; it had suggested a protective effect of omega- 3 fatty acids on breast cancer risk (Simopoulos, 2002). Decrease in $\omega 6 / \omega 3$ ratio may be due to inhibits ruminal biohydrogenation by secondary metabolites (Cabbidu et al., 2009). Similar to this study, Mapiye et al. (2010) showed that beef supplemented with Acacia karroo have lower $\omega 6 / \omega 3$ ratio from steers that received control diet. Additionally, Turner et al. (2005) reported that using birdsfoot trefoil (Lotus corniculatus) in dairy cows diet declined ruminal biohydrogenation and increased $\omega 3$ fatty acids. However, Cabbidu et al. (2009) showed that in sheep fed Sulla (contain 25-27 g condensed tannin/kg DM), had higher $\omega 6 / \omega 3$ ratio comparing to sheep fed Sulla plus polyethylene glycol. These researchers illustrated that this can be explained by the higher biohydrogenation activity of ruminal bacteria in the polyethylene glycol group, due to the partial inactivation of the tannins.

\section{Conclusions}

Adding PPE lowered BUN, MUN and blood cholesterol. Lower MUN suggested improved utilization of $\mathrm{N}$ when PPE was supplemented. Milk from cows fed PPE400 and
PPE800 had significantly lower SFA, desirable $\omega 6 / \omega 3$ ratio and higher content of EPA and DHA than milk from cows that received no PPE. It was suggested that milk from cows supplemented with PPE could be a healthier food from a human nutrition perspective. Feeding PPE to lactating cows could be a valuable mean for increasing the supply of PUFA to milk and consequently, improve the nutrition value of milk for human consumption.

\section{Conflicts of interest}

The authors wish to confirm that there are no known conflicts of interest associated with this publication and there has been no financial support for this work that could have influenced its outcome.

\section{Acknowledgement}

The authors would like to thank Iran National Science Foundation for the kind financial support for carrying out the trial.

\section{References}

Abarghuei, M.J., Rouzbehan, Y., Alipour, D., 2010. The influence of the grape pomace on the ruminal parameters of sheep. Livest. Sci. 132, 73-79.

Abarghuei, M.J., Rouzbehan, Y., Salem, A.Z.M., Zamiri, M.J., 2013. Nutrient digestion, ruminal fermentation and performance of dairy cows fed pomegranate peel extract. Livest. Sci. 157, 452-461.

Abarghuei, M.J., Rouzbehan, Y., Salem, A.Z.M., 2014. The influence of pomegranate-peel extracts on in vitro gas production kinetics of rumen inoculum of sheep. Turk. J. Vet. Anim. Sci. 38, 212-219.

Adams, L.S., Seeram, N.P., Aggarwal, B.B., Takada, Y., Sand, D., Heber, D., 2006. Pomegranate juice, total pomegranate ellagitannins, and punicalagin suppress inflammatory cell signaling in colon cancer cells J. Agric. Food Chem. 54, 980-985.

Alipour, D., Rouzbehan, Y., 2010. Effects of several levels of extracted tannin from grape pomace on intestinal digestibility of soybean meal Livest. Sci. 128, 87-91.

AOAC, 1990. 15th ed.Official Methods of Analysis, vol. I. Association of Official Analytical Chemists, Arlington, VA, USA.

Benchaar, C., McAllister, T.A., Chouinard, P.Y., 2008. Digestion, ruminal fermentation, ciliate protozoal populations, and milk production from dairy cows fed cinnamaldehyde, quebracho condensed tannin, or Yucca schidigera saponin extract. J. Dairy Sci. 91, 4765-4777.

Benchaar, C., Chouinard, P.Y., 2009. Short communication: assessment of the potential of cinnamaldehyde, condensed tannins, and saponins to modify milk fatty acid composition of dairy cows. J. Dairy Sci. 92, 3392-3396.

Benchaar, C., Chaves, A.V., Fraser, G.R., Wang, Y., Beauchemin, K.A. McAllister, T.A., 2007. Effects of essential oils on digestion, rumina fermentation, rumen microbial populations, milk production, and milk composition in dairy cows fed Alfalfa Silage or Corn Silage. J. Dairy Sci. 90, 886-897.

Brenna, J.T., Salem, N., Sicalir, A.J., Cunnane, S.C., 2009. International Society for the Fatty acids and Lipids (ISSFAL). Alpha-linolenic acid supplementation and conversion to $n-3$ long-chain polyunsaturated fatty acids in humans. Prostaglandins Leukot. Essent. Fatty Acids. 80, 85-91.

Burdge, G.C., Calder, P.C., 2005. Conversion of $\alpha$-linolenic acid to longerchain polyunsaturated fatty acids in human adults. Rep. Nutr. Develop 45, 581-597.

Cabbidu, A., Molle, G., Decandia, M., Spada, S., Fiori, M., Piredda, G., Addis, M. 2009. Responses to condensed tannins of flowering sulla (Hedysarumcoronarium L.) grazed by dairy sheep. Part 2: effects on milk fatty acid profile. Livest. Sci. 123, 230-240. 
Cannas, A., Pes, A., Mancuso, R., Vodret, B., Nudda, A., 1998. Effect of dietary energy and protein concentration on the concentration of milk urea nitrogen in dairy ewes. J. Dairy Sci. 82, 499-508.

Chiofalo, V., Liotta, L., Fiumanò, R., BenedettaRiolo, E., Chiofalo, B., 2012. Influence of dietary supplementation of Rosmarinu sofficinalis L. On performances of dairy ewes organically managed. Small Rumin. Res 104, 122-128.

Chouinard, P.Y., Lévesque, J., Girard, V., Brisson, G.J., 1997. Dietary soybeans extruded at different temperatures: milk composition and in situ fatty acid reactions. J. Dairy Sci. 80, 2913-2924.

Cowan, M.M., 1999. Plant products as antimicrobial agents. Clin. Microbiol. Rev. 12, 564-582.

Durmic, Z., McSweeney, C.S., Kemp, G.W., Hutton, P., Wallace, R.J., Vercoe, P.E., 2008. Australian plants with potential to inhibit bacteria and processes involved in ruminal biohydrogenation of fatty acids. Anim. Feed Sci. Technol. 145, 271-284.

Farnworth, E.R., Chouinard, P.Y., Jacques, H., Venkatramanan, S., Mafu, A.A., Defnoun, S., Jones, P., 2007. The effect of drinking milk containing conjugated linoleic acid on fecal microbiological profile, enzymatic activity, and fecal characteristics in humans. J. Nutr. 6, 1-15.

Fed. Anim. Sci. Soc.3rd ed. Champaign, IL.

Francis, G, Kerem, Z., Makkar, H.P.S., Becker, K., 2002. The biological action of saponins in animal systems: a review. Br. J. Nutr. 88, 587-605.

Givens, D.I., 2010. Milk and meat in our diet: good or bad for health? Animal 4, 1941-1952.

Harris, W.S., Mozaffarian, D., Lefevre, M., Toner, C.D., Colombo, J., Cunnane, S.C., Holden, J.M., Klurfeld, D.M., Morris, M.C., Whelan, J., 2009. Towards establishing dietary reference intakes for eicosapentaenoic and docosahexaenoic acids. J. Nutr. 139, 804S-819S.

Hassan, A., Ibrahim, A., Mbodji, K., Coeffier, M., Ziegler, F., Bounoure, F., Chardigny, J.M., Skiba, M., Savoye, G., Dechelotte, P., 2010. An alinolenic acid-rich formula reduces oxidative stress and inflammation by regulating NF-kB in rats with TNBS-induced colitis. J. Nutr. 140 1714-1721.

Khiaosa-Ard, R., Bryner, S.F., Scheeder, M.R.L., Wettstein, H.R., Leiber, F. Kreuzer, M., Soliva., C.R., 2009. Evidence for the inhibition of the terminal step of ruminal $\alpha$-linolenic biohydrogenation by condensed tannins. J. Dairy Sci. 92, 177-188.

Jiménez-Peralta, F.S., Salem, A.Z.M., Mejia-Hernández, P., GonzálezRonquillo, M., lbarrán-Portillo, B., Rojo-Rubio, R., Tinoco-Jaramillo, J.L., 2011. Influence of individual and mixed extracts of two tree species on in vitro gas production kinetics of a high concentrate diet fed to growing lambs. Livest. Sci. 136, 192-200.

Makkar, H.P.S., Sen, S., Blummel, M., Becker, K., 1998. Effects of fractions containing saponins from Yucca schidigera, Quillaja saponaria and Acacia auriculoformis on rumen fermentation. J. Agric. Food Chem. 46 4324-4328.

Makkar, H.P.S., Blümmel, M., Becker, K., 1995. in vitro effects and interactions of tannins and saponins and fate of tannins in the rumen. J. Sci. Food Agric. 69, 481-493.

Makkar, H.P.S., 2000. Quantification of Tannins in Tree Foliage. A Laboratory Manual for the FAO/IAEA Co-ordinated Research Project on Use of Nuclear and Related Techniques to Develop Simple Tannin Assays for Predicting and Improving the Safety and Efficiency of Feeding Ruminants on Tanniniferous Tree Foliage. Joint FAO/IAEA of Nuclear Techniques in Food and Agriculture. Animal Production and Health Sub-Programme, FAO/IAEA Working Document. IAEA, Vienna, Austria.

Makkar, H.P.S., 2003. Effects and fate tannins in ruminant animals, adaptation to tannins, and strategies to overcome detrimental effects of feeding tannin-rich feeds. Small Rumin. Res. 49, 241-256.

Mapiye, C., Chimonyo, M., Dzama, K., Strydom, P.E., Muchenje, V., 2010 Meat quality attributes of Nguni steers supplemented with Acacia karroo leaf-meal. Meat Sci. 8, 621-627.

McAfee, A.J., McSorley, E.M., Cuskelly, G.J., Moss, B.W., Wallace, J.M.W. Bonham, M.P., Fearon, A.M., 2010. Red meat consumption: an overview of the risks and benefits. Meat Sci. 84, 1-13.

Micha, R., Wallace, S.K., Mozaffarian, D., 2010. Red and processed meat consumption and risk of incident coronary heart disease, stroke, and diabetes mellitus A systematic review and meta-analysis. Circulation $121,2271-2283$.

Mirzaei-Aghsaghali, A., Maheri-Sis, N., Mansouri, H., Razeghi, M.E., Mirza-Aghazadeh, A., Cheraghi, H., Aghajanzadeh-Golshani, A., 2011. Evaluating potential nutritive value of pomegranate processing by-products for ruminants using in vitro gas production technique. ARPN J. Agric. Biol. Sci 6, 45-51.

Molendi-Coste, O., Legry, V., Leclercq, I.A., 2011. Review article: Why and how meet n-3 PUFA dietary recommendations? Gastroenterol. Res. Practice, 2011.
Mueller-Harvey, I., 2006. Review, unraveling the conundrum of tannins in animal nutrition and health. J. Sci. Food Agric. 86, 2010-2037.

Nasri, S., Ben Salem, H., 2012. Effect of oral administration of Agave americana or Quillaja saponaria extracts on digestion and growth of Barbarine female lamb. Livest. Sci. 147, 59-65.

NRC, 2001. Nutrient requirements of dairy cattle. 7th rev. ed. Natl. Acad. Sci., Washington, DC.

Oakenfull, D., Sidhu, G.S., 1989. Saponins. In: Cheeke, P.R. (Ed.), Toxicants of Plant Origin, vol. 2. , CRC Press, Boca Raton, FL, pp. 97-141.

Oliveira, R.A., Narciso, C.D., Bisinotto, R.S., Perdomo, M.C., Ballou, M.A., Dreher, M., Santos, J.E.P., 2010. Effects of feeding polyphenols from pomegranate extract on health. Growth, nutrient digestion, and immunocompetence of calves. J. Dairy Sci. 93, 4280-4291.

Salem, A.Z.M., Kholif, A.E., Olivares, M., Elghandour, M.M.Y., Mellado, M. Arece, J., 2014a. Influence of S. babylonica extract on feed intake, growth performance and diet in vitro gas production profile in young lambs. Trop. Anim. Health Prod. 46, 213-219.

Salem, A.Z.M., Kholif, A.E., Elghandour, M.M.Y., Buendía, G., Mariezcurrena, M.D., Hernandez, S.R., et al., 2014b. Influence of oral administration of Salix babylonica extract on milk production and composition in dairy cows. Ital. J. Anim. Sci. 13, 10-14.

Salem, A.Z.M., Olivares, M., Lopez, S., Gonzalez-Ronquillo, M., Rojoc, R., Camacho, L.M., Cerrillo, S.M.A., Mejia, H.P., 2011. Effect of natural extracts of Salix babylonica and Leucaena leucocephala on nutrient digestibility and growth performance of lambs. Anim. Feed Sci. Technol. 170, 27-34.

Shi, J., Arunasalam, K., Yeung, D., Kakuda, Y., Mittal, G., Jiang, Y., 2004. Saponins from edible legumes: chemistry, processing, and health benefits. J. Med. Food. 7, 67-78.

Simopoulos, A.P., 2002. The importance of the ratio of omega-6/omega-3 essential fatty acids. Biomed. Pharmacother 56, 365-379.

Sinclair, L.A., Hart, K.J., Wilkinson, R.G., Huntington, J.A., 2009. Effects of inclusion of whole-crop ensilages differing in their tannin content on the performance of dairy cows fed high or low protein concentrates. Livest. Sci. 124, 306-313.

Siri-Tarino, P.W., Sun, Q., Hu, F.B., Krauss, R.M., 2010. Saturated fatty acids and risk of coronary heart disease: modulation by replacement nutrients. Curr. Atheroscler. Rep 12, 384-390.

Smit, L.A., Mozaffarian, D., Willett, W., 2009. Review of fat and fatty acid requirements and criteria for developing dietary guidelines. Ann. Nutr. Metab. 55, 44-55.

Steijns, J.M., 2008. Dairy products and health: Focus on their constituents or on the matrix? Int. Dairy J 18, 425-435.

Sukhija, P., Palmquist, D.L., 1988. Rapid method for determination of total fatty acid content and composition of feedstuffs and feces. J. Agric. Food Chem. 36, 1202-1206.

Topps, J.H., Thompson, J.K., 1984. Blood characteristics and the nutrition of ruminants. MAFF Reference Book. HMSO, London260.

Turner, S.A., Waghorn, G.C., Woodward, S.L., Thomson, N.A., 2005. Condensed tannins in birdsfootrefoil (Lotus corniculatus) affect the detailed composition of milk from dairy cows. N.Z. Soc. Anim. Prod. 65, 283-289.

USDA and HHS, 2010. Dietary Guidelines for Americans 2010. Department of Health and Human Services (HHS)/Department of Agriculture (USDA) Available from 〈http://www.cnpp.usda.gov/DGAs2010-DGA CReport.htm〉.

Vaithiyanathan, S., Bhatta, R., Mishra, A.S., Prasad, R., Verma, D.L., Singh, N.P., 2007. Effect of feeding graded levels of Prosopis cineraria leaves on rumen ciliate protozoa, nitrogen balance and microbial protein supply in lambs and kids. Anim. Feed Sci. Technol. 133, 117-191.

Valadares, R.F.D., Broderick, G.A., Valadares Filho, S.C., Clayton, M.K., 1999. Effect of replacing alfalfa silage with high moisture corn on ruminal protein synthesis, estimated from excretion of total purine derivatives. J. Dairy Sci. 82, 2686-2696.

Van Soest, P.J., Robertson, J.B., Lewis, B.A., 1991. Methods for dietary fiber, neutral detergent fiber, and nonstarch poly-saccharides in relation to animal nutrition. J. Dairy Sci. 74, 3583-3597.

Vasta, V., Nuddab, A., Cannas, A., Lanza, M., Priolo, A., 2008. Alternative feed resources and their effects on the quality of meat and milk from small ruminants. Anim. Feed Sci. Technol. 147, 223-246.

Vasta, V., Priolo, A., Scerra, M., Hallett, K.G., Wood, J.D., Doran, O., 2009. $\Delta 9$ desaturase protein expression and fatty acid composition of longissimusdorsi muscle in lambs fed herbage or concentrate with or without tannins. Meat Sci. 82, 357-364.

Wina, E., Mutetzel, S., Becker, K., 2005. The impact of saponin-containing plant aterials on ruminant production-a review. J. Agri. Food Chem. 53, 8093-8105. 
Woodward, A., 1988. Chemical composition of browse in relation to relative consumption of species and nitrogen metabolism of livestock in southern Ethiopia (Ph.D. dissertation). Cornell University, Ithaca, NY.

Woodward, A., Reed, J.D., 1997. Nitrogen metabolism of sheep and goats consuming Acacia brevispica and Sesbania sesban. J. Anim. Sci. 75, 1130-1139.

Yang, W.Z., Benchaarb, C., Ametaj, B.N., Beauchemin, K.A., 2010. Dose response to eugenol supplementation in growing beef cattle: ruminal fermentation and intestinal digestion. Anim. Feed Sci. Technol. 158, 57-64.

Zhao, G., Etherton, T.D., Martin, K.R., Gllies, P.J., West, S.G., Kris-Etherton, P.M., 2007. Dietary alpha-linolenic acid inhibits proinflammatory cytokine production by peripheral blood mononuclear cells in hypercholesterolemic subjects. Am. J. Clin. Nutr. 85, 385-391. 